\title{
IDENTIFICATION OF STAKEHOLDERS' ROLE IN THE SOCIAL ENTREPRENEUR OF SEA CULTIVATION OF VANAME SHRIMP (Litopenaeus vannamei)
}

\author{
Luthfa Jamilah")1, Mukhamad Najib**), and Kirbrandoko $\left.{ }^{* * *}\right)$ \\ ${ }^{*}$ School of Business, IPB University \\ Jl. Pajajaran, Bogor 16151, Indonesia \\ **) Department of Management, Faculty of Economics and Management, IPB University \\ Jl. Agatis, Campus of IPB Darmaga Bogor 16680, Indonesia \\ ${ }^{* * *}$ Ibn Khaldun Bogor University \\ Jl. Sholeh Iskandar, Kedungbadak, Tanah Sereal, Bogor 16162, Indonesia
}

\begin{abstract}
Mariculture of vaname shrimp, which is based on the social entrepreneur, is one of the strategies to improve the coastal welfare community. This concept focuses on enhancing the community's economy and environmental sustainability. To succeed in the business, an active role and stakeholder involvement is needed. This study aims to identify and map the role of stakeholders that influences business activities. Data analysis is carried out descriptively based on the results of identification, the typology classification, and the analysis of Dependence Mapping. The results of the study state that the role of stakeholders is divided into the internal and the external. The typology classification shows the educational institutions expect the role of definite owned by the group leader, the research and suppliers, the latent-discretionary by operational and marketing executives, the expected-dangerous by local governments, provincial governments and community leaders, the latent-dormant by the mass media and NGOs, the latent-discretionary by private companies, the latent demanding by financial institutions and MSMEs, and the expected-dependent by end consumers. The groups of stakeholders that influence the business are 1) High Interdependence consisting of group leaders, operational executors, finance and marketing, suppliers and private companies, and 2) Power Stakeholders consisting of end consumers, community leaders, local governments, educational and research institutions.
\end{abstract}

Keywords: social entrepreneur, stakeholder, vaname, dependence mapping

Abstrak: Budidaya udang vaname, yang didasarkan pada wirausaha sosial, merupakan salah satu strategi untuk meningkatkan kesejahteraan masyarakat pesisir. Konsep ini berfokus pada peningkatan ekonomi masyarakat dan kelestarian lingkungan. Untuk berhasil dalam bisnis, peran aktif dan keterlibatan pemangku kepentingan diperlukan. Penelitian ini bertujuan mengidentifikasi dan memetakan peran pemangku kepentingan yang memengaruhi kegiatan bisnis. Analisis data dilakukan secara deskriptif berdasarkan hasil identifikasi, klasifikasi tipologi, dan analisis dependence mapping. Hasil penelitian menyatakan bahwa peran pemangku kepentingan dibagi menjadi internal dan eksternal. Klasifikasi tipologi menunjukkan lembaga-lembaga pendidikan mengharapkan peran yang pasti dimiliki oleh pemimpin kelompok, penelitian dan pemasok, laten-diskresi oleh eksekutif operasional dan pemasaran, yang diperkirakan berbahaya oleh pemerintah daerah, pemerintah provinsi dan pemimpin masyarakat, laten- dorman oleh media massa dan LSM, laten-diskresi oleh perusahaan swasta, laten menuntut oleh lembaga keuangan dan UMKM, dan tergantung pada konsumen akhir yang diharapkan. Kelompok-kelompok pemangku kepentingan yang memengaruhi bisnis adalah 1) Saling ketergantungan tinggi yang terdiri dari pemimpin kelompok, pelaksana operasional, keuangan dan pemasaran, pemasok dan perusahaan swasta, dan 2) Stakeholder yang terdiri dari konsumen akhir, pemimpin masyarakat, pemerintah daerah, lembaga pendidikan dan penelitian .

Kata kunci: wirausaha sosial, pemangku kepentingan, vaname, dependence mapping

\footnotetext{
${ }^{1}$ Corresponding author:

Email: luthfa.jamilah@gmail.com
} 


\section{INTRODUCTION}

As much as $70 \%$ of Indonesia's territory is the waters area that has the potential to improve the economy, primarily through the coastal communities. However, the seasonal uncertainty and weather conditions are the factors that cause the welfare of fishers to fluctuate. This is compounded by the imbalance in the use of fisheries resources, where $90 \%$ of the 2.8 million small fishermen in Indonesia only bring home an average of two kilograms of fish per day (Deny, 2014). To overcome this, it is generally carried out by developing an inland fisheries business (pond). Vaname shrimp is one of the excellent commodities that is cultivated in ponds because it has high productivity (SR $85-90 \%$ ).

The rise of pond vaname shrimp business raises several social and environmental problems. Hidayatillah (2017) concluded in her research that although the existence of shrimp pond industrialization can create employment, these efforts also cause social and environmental problems. Three big issues faced are the land pollution on the productive agricultural land which becomes unproductive, the pollution of seawater that becomes itchy and smelly, and also the air pollution arising from the activity of the shrimp pond. Responding to this, the larger sea areas compared to the land can be used to be the alternative solutions to the aquaculture activities.

The use of the sea as the place of cultivation (mariculture) of vaname shrimp is a breakthrough that has been made by Pusat Kajian Sumberdaya Pesisir dan Lautan (PKSPL) IPB. The development of the technology of mariculture is one of the solutions to restore the natural function of the sea. The activities that have been carried out since 2015 are one of the forms of contribution to the coastal communities, especially in Kepulauan Seribu. The success of PKSPL in developing the sea shrimp cultivation technology that involves the community can be an alternative livelihood for the local fishermen. Several groups of fishermen can manage the activities to improve joint economic welfare. In 2015-2016, PKSPL succeeded in involving 79 fishers in the action research; the number is then drastically reduced so that the cultivation is not optimal. The enthusiasm of the community towards the high sea shrimp cultivation is not facilitated and properly accommodated because the activities are still project-based. In fact, the community involvement in this activity can be business learning (the social entrepreneur) that is carried out and is aimed at increasing the shared welfare.
Some obstacles that can hinder the implementation and the continuity of cultivation business include business management, the productivity that is not maximal, and the absence of the groups of fishermen who play a unique role as the business managers. According to Surya et al. (2002), weak business management capabilities are one of the strategic points to the causes of poverty and the helplessness of fishers and coastal communities. The concept of national development must be directed at utilizing various existing regional resources. According to Surya et al. (2002), the development mission must lead to the sustainability of sustainable people (sustainable people-centered development). For this reason, the active role of stakeholders is needed both internally and externally. A good understanding of the interests of the stakeholders in the social entrepreneur business is needed to improve the business synergy of various parties.

Moving on from that understanding, the stakeholder analysis on the vaname shrimp cultivation social entrepreneur is aimed at gaining an understanding from interested parties in the vaname sea shrimp cultivation business to establish harmonious business synergy between the stakeholders and the community as the business actors. In addition, the understanding of the role of stakeholders in a business can also reduce the risk of failure and help the management rationally and systematically to understand the complex relationships, to understand the values and supporting issues, and the threats that can arise from the stakeholders (Susanto, 2015). The stakeholders are the partners of an organization, both those that have a direct or indirect relationship. Many or at least stakeholders involved in a business are very dependent on the size of the business. The higher the efforts carried out, the more involved stakeholders will be and vice versa. The existence of these stakeholders is considered to have strengths that can influence the achievement of the business objectives and become a trigger for the occurrence of the business model innovation. Osterwalder and Pigneur (2015) emphasize that a company needs to create an alliance (partner) to optimize the business models, to reduce the risks, or to obtain the resources from them.

\section{METHODS}

The research is conducted in Semak Daun Island, Kepulauan Seribu, in August - October 2018. The study is carried out by the descriptive method. The data used 
are primary data and secondary data. The primary data are obtained from the result of the observation and indepth interviews. The secondary data are obtained from the Central Bureau of Statistics, Ministry of Industry, Ministry of Trade, Ministry of Maritime Affairs and Fisheries, the research data of PKSPL-IPB, and other data sources relevant to the research topics such as the scientific journals, the books, the proceedings, the working papers, and others. The phases of research include the identification of stakeholders, the typology classification, and the stakeholder analysis based on the dependency mapping. The framework for research thinking can be briefly seen in Figure 1 .

\section{RESULTS}

\section{Regional Overview}

The Administrative District of Kepulauan Seribu (KAKS) is located in Jakarta Bay and Jakarta Sea, which part of the area is the ocean of $6,997.5 \mathrm{~km}^{2}$ and the land area of $8.70 \mathrm{~km}^{2}$. Geographically, the northern part of the KAKS borders the Java Sea or the Sunda Strait, the east of the Java Sea, the south with the Administrative City of North Jakarta, the Administrative City of West Jakarta and Tangerang District, and the west with the Java Sea / Sunda Strait.

The area of KAKS has 110 islands and is administratively divided into two sub-districts, namely Sub-district of
Kepulauan Seribu Utara (79 islands) and Sub-district of Kepulauan Seribu Selatan (31 islands). The number of kelurahan KAKS is six kelurahan, consisting of three sub-districts in Kepulauan Seribu Utara (Kelapa Island, Kelurahan Harapan Island, and Kelurahan Panggang Island), and three sub-districts in Kepulauan Seribu Selatan (Kelurahan Tidung Island, Kelurahan Pari Island, and Kelurahan Untung Jawa Island).

The community of KAKS consists of several tribes, including Bugis, Banten, Madura, and Betawi. The number of population of KAKS in 2016 is 23,639 people, with the composition of 11,816 male and 11,823 female. The annual population growth rate is $1.02 \%$ with a population density of 2.72 people $/ \mathrm{km}^{2}$ and a gender ratio of $99.94 \%$. Most of the people's livelihoods are fishermen and some work as traders and services (especially the transportation services).

The Vision and Mission of KAKS is "Realizing Kepulauan Seribu as Sustainable Field and Marine Life Parks", therefore the policy of KAKS development is directed at increasing the tourism activities, improving the quality of life of the fishermen communities by enhancing the marine cultivation, utilizing the fisheries resources by conserving the coral reef and mangrove ecosystems. The Regional Regulation No. 55/2001 dated 3 July 2001 also stipulates that the communitybased coastal, marine, and small islands development (community development), to increase the diversity of the livelihood sources of the local communities.

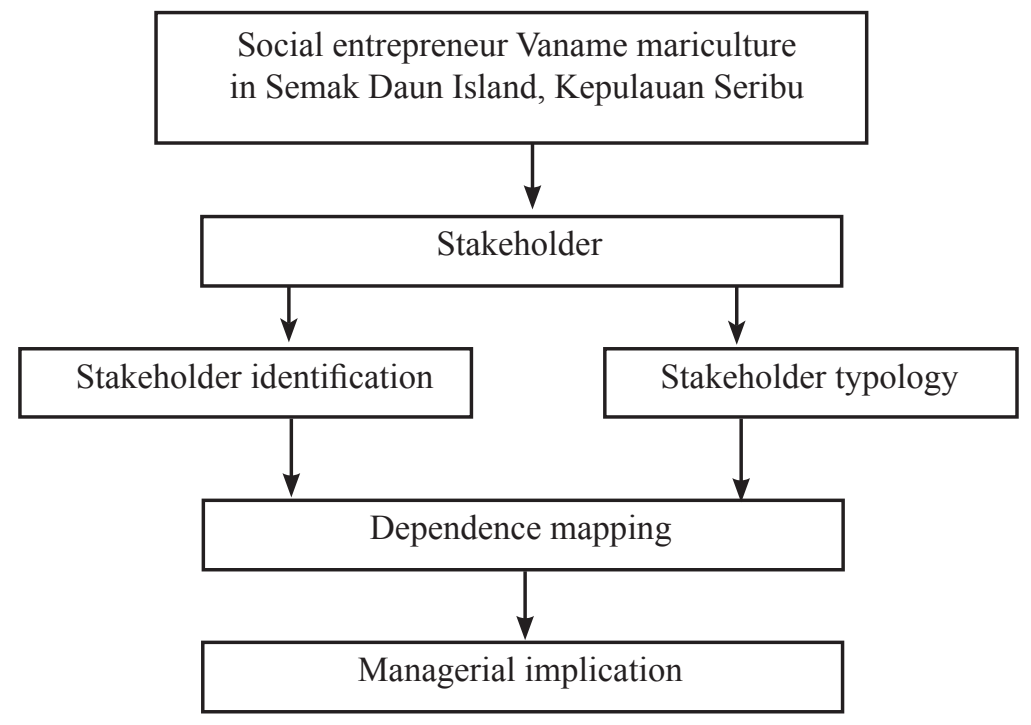

Figure 1. Research framework 
The location of the sea shrimp cultivation is on Semak Daun Island, which is part of Sub-district of Kepulauan Seribu Utara, which has three large kelurahan, namely Panggang Island, Kelapa Island, and Harapan Island. Kelurahan Panggang island has a land area of 62.1 Ha having 13 islands (Table 1). Two islands are the residential areas, namely Panggang Island and Pramuka Island, and eleven other islands are uninhabited islands and are used for various community interests, such as rest areas, conservation areas, cultivation/mariculture areas, tourist areas, and lighthouses.

The demographic effects of the island areas whose territory is surrounded by waters and coastal areas result in the livelihoods of the local people being fishermen. The most dominant ethnic group is the Bugis tribe, who are the sailors. Nearly $70 \%$ of the people in Kelurahan Panggang Island are fishermen, both capture fishers or cultivators or seasonal seaweed fishers, and the rest works in the trade service sector, the government employees, and the laborers (Table 2). The composition of the community education level in this area is that $39.21 \%$ do not graduate from SD, $43.01 \%$ graduate from SD, 9.59\% graduate from SLTP, 7.19\% graduate from SLTA, 1.17\% graduate from Academy / Diploma, and $0.51 \%$ graduate to become Sarjana.

Semak Daun Island (Figure 2) is part of Kelurahan Panggang Island, which is used as an area of forest protection and nature conservation. Semak Daun Island has a characteristic that is the protected shallow marine waters or often referred to as the relatively wide scorched waters. Based on the principle of the protection of the shallow marine waters around the island, the area has high potential as the maricultural area. Besides, Semak Daun Island, Karang Congkak Island, and Karang Bongkok Island also have almost similar characteristics of the waters. Semak Daun Island is the uninhabited island and based on the regional characteristics which are used as the collaborative management efforts that can enhance and restore the marine ecosystem.

Table 1. List of the Areas of Kelurahan Panggang Island

\begin{tabular}{llcc}
\hline Island Name & Designation & Area (Ha) & Percentage (\%) \\
\hline Opak Kecil Island & Rest Area & 1.10 & 1.77 \\
Karang Bongkok Island & Rest Area & 0.50 & 0.81 \\
Kotok Kecil Island & General Forest Protection & 1.30 & 2.09 \\
Kotok Besar Island & Tourism & 20.75 & 33.41 \\
Karang Congkak Island & Rest Area & 0.60 & 0.97 \\
Gosong Pandan Island & Rest Area & 0.00 & 0.00 \\
Semak Daun Island & Forest Protection and Nature Conservation & 0.75 & 1.21 \\
Panggang Island & Settlement & 9.00 & 14.49 \\
Karya Island & Offices & 6.00 & 9.66 \\
Pramuka Island & Settlement & 16.00 & 25.77 \\
Gosong Sekati Island & Rest Area & 0.20 & 0.32 \\
Air Island & Rest Area & 2.90 & 4.67 \\
Peniki Island & Lighthouse & 3.00 & 4.83 \\
\hline Total & & 62.10 & 100.00 \\
\hline
\end{tabular}

Source: Data on the Annual Report of Kelurahan Panggang Island (2008)

Table 2. Total population based on the employment in the Sub-district of Kepulauan Seribu Utara

\begin{tabular}{lccccc}
\hline Kelurahan & Fisherman & Trader & PNS/TNI/Polri & Laborer & Others \\
\hline Panggang Island & 1,567 & 102 & 247 & 22 & 75 \\
Kelapa Island & 1,058 & 261 & 78 & 169 & 3 \\
Harapan Island & 287 & 111 & 47 & 337 & 909 \\
Total & 2,912 & 474 & 372 & 528 & 987 \\
\hline
\end{tabular}

Source: BPS (2018) 


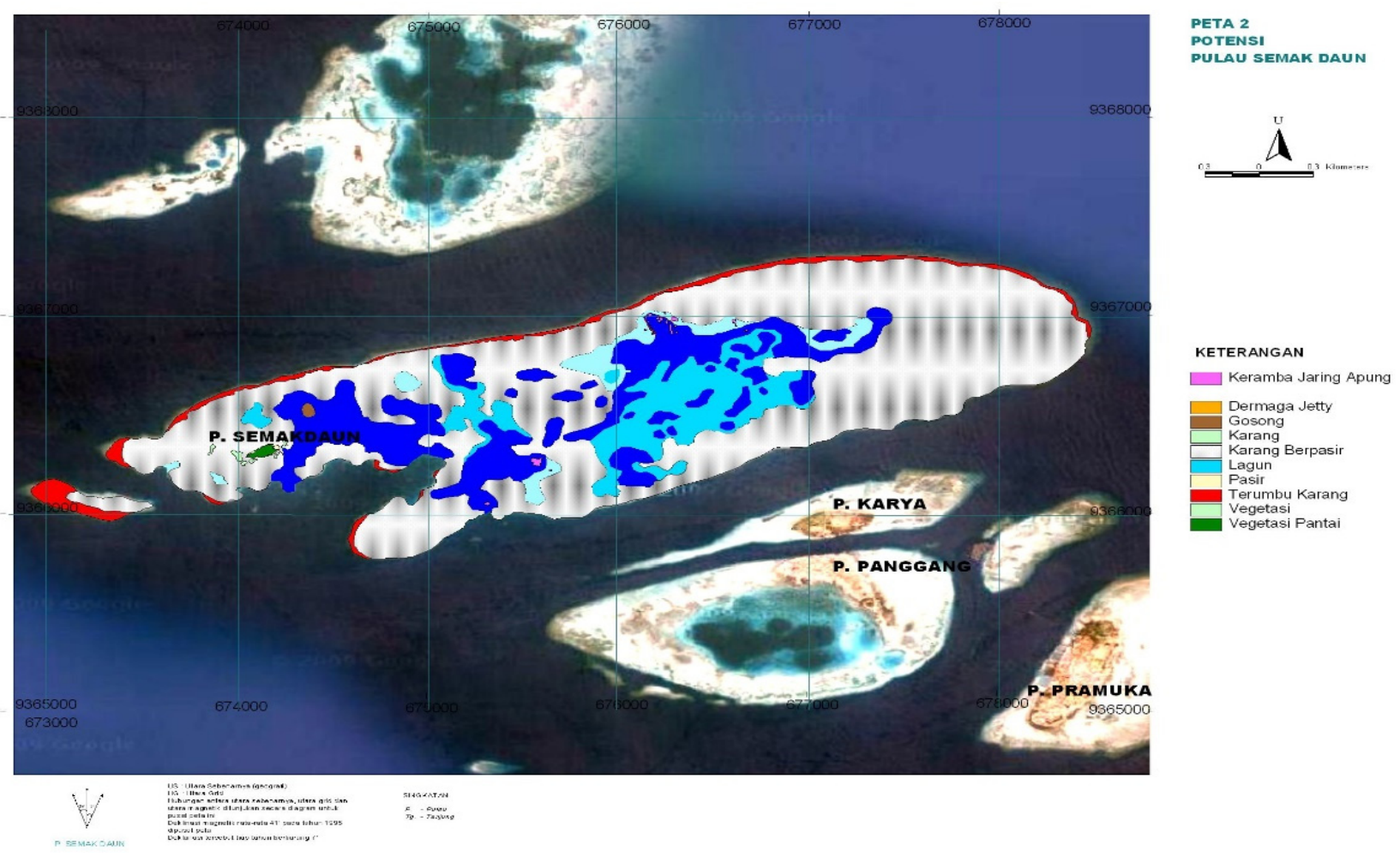

Figure 2. Area map of Semak Daun Island

\section{Identification of Stakeholders}

The identification of the stakeholders to know who the company interacts with, both in the process of achieving the goals or for other purposes. Knowing and recognizing from the beginning who the stakeholders are involved is important because the organization has an interest in each of them and vice versa. Identifying the stakeholders at the same time can be used as an initial step in preparing and classifying the stakeholders in the next phase. According to Susilo and Kaho (2011), the key to the successful implementation of this technique is the ability to compile a list of stakeholders as much as possible and map them, so that they can identify all potentials and risks that may occur as a result of the conflicts of interests with the stakeholders or the failure of the company to fulfill its obligations.

The identification of the stakeholders of the vaname shrimp cultivation business is grouped into two, namely the internal stakeholder and the external stakeholder. The internal stakeholder is the individual or the group involving directly or indirectly in the company's business cycle, while the external stakeholder is the group of people or the organization that is indirectly involved in the business process but has the influence on the course of the business. The results of the stakeholder identification obtained based on the opinions of the experts are seen in Table 3.

\section{Typology of Stakeholders}

Stakeholder classification is carried out after the identification process. This process is carried out to determine the stakeholder priorities based on the level of power possessed. This is necessary because the companies face so many stakeholders that they need to understand their respective characteristics. Determining their handling priorities to support the company's business development effectively. The first step to classify is to identify 3 (three) stakeholder attributes, namely power, legitimacy, and urgency, or the combination of the three. The power is a force that can carry out its desires despite the opposition. The legitimacy (the right) is an action that is expected to be appropriate and in accordance with a social system order based on the norms, the belief values, and the definitions. The urgency (urgent situation) is a demand for immediate attention.

Based on 3 (three) attributes owned, the stakeholder typology is grouped into 3 (three), namely 1) The latent stakeholder - the typology that only has one attribute, including the dormant stakeholder (power), the discretionary stakeholder (legitimacy), and the demanding stakeholder (urgency), 2) The expected stakeholder - the typology that has the combination between two attributes, including the dominant stakeholder (power and legitimacy), the dependent 
stakeholder (legitimacy and urgency), and the dangerous stakeholder (urgency and power), and 3) The definitive stakeholder - the typology that has three attributes of stakeholder so that with the highest silence level so that the voice will dominate and have a significant effect on the company performance. The results of the classification of each stakeholder are as shown in Table 4.

\section{Internal Stakeholder}

\section{Group Leader}

The group leader is a member of the community involved in the business activities and has full responsibility for carrying out the activities. The group leader can come from the people who have the greatest capital for the conduct of businesses or the people who have the most influence on the local group and the community. The group leader is classified as a definite stakeholder because he has power, legitimacy, and urgency. As the highest leader in the aquaculture activities, the power of the group leader is in the form of power to regulate the business turnaround starting from planning to product acceptance by the consumers. The legitimacy is in the form of legitimate authority in regulating the business arrangements both internally and with external parties involving outside parties. In the precarious conditions, the group leader can also urge his group members to stop or carry out the business activities.

Table 3. Identification of the social entrepreneur stakeholders in the vaname cultivation business

\begin{tabular}{ll}
\hline \multicolumn{1}{c}{ External } & Stakeholders \\
\hline Regional Government & \\
- Local Government (RT/RW) & Group Leader \\
- District/City Government & Technical Executor \\
Central Government (Provincial Government) & - Finance \\
- Education and Research Institute & - Operational \\
- University & - Marketing \\
- Research Institute & \\
Media & \\
- Social Media & \\
- Mass Media (Printed/Electronic) & \\
Private Company & \\
Non-Governmental Organization (NGO) & \\
- Environment NGO & \\
- Community Empowerment NGO & \\
Financial Institution & \\
- Cooperative & \\
- Bank & \\
Small and Medium Enterprise (SME) & \\
Public Figure & \\
- Customary Figure & \\
- Religious Leader & \\
Supplier & \\
- Feed Supplier & \\
- Seed Supplier & \\
End Consumer & \\
- End User & \\
- Restaurant & \\
Coastal Community & \\
Travel Agent Industry & \\
\hline & \\
\hline
\end{tabular}


Table 4. Classification of the social entrepreneur stakeholders in the vaname shrimp cultivation

\begin{tabular}{|c|c|c|c|c|}
\hline \multirow{2}{*}{ Stakeholders } & \multicolumn{3}{|c|}{ Attribute } & \multirow{2}{*}{ Classification } \\
\hline & Power & Legitimacy & Urgency & \\
\hline \multicolumn{5}{|l|}{ INTERNAL } \\
\hline Group Leader & $\sqrt{ }$ & $\sqrt{ }$ & $\sqrt{ }$ & Definitive \\
\hline Financial Technical Implementer & & $\sqrt{ }$ & & Latent - Discretionary \\
\hline Operational Technical Implementer & & $\sqrt{ }$ & & Latent - Discretionary \\
\hline Technical Marketing Implementer & & $\sqrt{ }$ & & Latent - Discretionary \\
\hline \multicolumn{5}{|l|}{ EXTERNAL } \\
\hline Central Government & $\sqrt{ }$ & & $\sqrt{ }$ & Expected - Dangerous \\
\hline Regional Government & $\sqrt{ }$ & & $\sqrt{ }$ & Expected - Dangerous \\
\hline Education and Research Institute & $\sqrt{ }$ & $\sqrt{ }$ & & Expected - Dominant \\
\hline Mass Media & $\sqrt{ }$ & & & Latent - Dormant \\
\hline Private Company & & $\sqrt{ }$ & & Latent - Discretionary \\
\hline Non-Governmental Organization (NGO) & $\sqrt{ }$ & & & Latent - Dormant \\
\hline Financial Institution & & & $\sqrt{ }$ & Latent - Demanding \\
\hline UMKM & & & $\sqrt{ }$ & Latent - Demanding \\
\hline Public Figure & $\sqrt{ }$ & & $\sqrt{ }$ & Expected - Dangerous \\
\hline Supplier & $\sqrt{ }$ & & $\sqrt{ }$ & Expected - Dominant \\
\hline End Consumer & & $\sqrt{ }$ & $\sqrt{ }$ & Expected-Dependent \\
\hline Travel Agent Industry & & & $\sqrt{ }$ & Latent - Demanding \\
\hline
\end{tabular}

Financial, operational, and marketing technical implementers

It is a member of the business group that has a unique role related to the financial, operational, and marketing of aquaculture products. This division of roles is carried out to improve the business management to act more professionally. All three have typologies as the latent - discretionary stakeholders, which only have a single power in the form of legitimacy in the conduct of the business. Each of these internal stakeholders has the authority to improve the effectiveness of financial, operational, and business marketing.

\section{External Stakeholder}

Central Government (Provincial Government) and Regional Government

Environmental Law, Regional and National Government Regulations on the utilization of the environmental areas. The change in the law which regulates the zoning permits for the use of coastal and marine areas makes the policy fragmented, confusing the business people in managing the permits. One of the regulations changes made by the government is Law No.23 in 2014 concerning the Regional Government which regulates the expansion of the provincial authority in the marine sector. The Law will become effective in 2017. The changes contained include the provincial authority, which initially begins from 4-12 miles now it is expanded to 0-12 miles. Meanwhile, the area of 0-12 miles is the area closest to the district/city. This has caused the difficulties for the fishermen and the coastal business actors in forming the permits because they automatically remove the authority of the district/city in giving the permits and conducting the supervision. This power is considered the expected dangerous force because of the power and the urgency in the field of business regulation.

Education and Research Institute

This stakeholder has an important role in the innovative development of more productive vaname sea shrimp cultivation both in quality and quantity. The existence of an educational and research institute will significantly support the sea shrimp business, by providing the research results that can become a guide for implementing a better shrimp business. The lack of development of technological innovation and research on the vaname shrimp cultivation has made this business growth still low in Indonesia. Good cooperation with the stakeholders can be the key to 
developing and increasing the business scale in response to seizing opportunities. The product characteristics are considered to be important because basically the vaname sea shrimp can have better product quality than the pond shrimp caused by the seawater salinity.

\section{Mass Media}

Mass media, both print, electronic and social media have a role in informing the sea shrimp aquaculture activities that produce better quality than with the shrimp can and the environmentally friendly technology. These stakeholders are latent - dormant because they will only be active in voicing this out when they get rewards from the business actors.

\section{Private Company}

The role of the private company in the vaname shrimp cultivation business is as a provider of CSR (Corporate Social Responsibility) fund and the business activity cooperation partners. In accordance with the provision of article 74 of Law Number 40 in 2007 concerning the Limited Liability Companies, the private companies are obliged to provide CSR. Based on this law, private companies can be involved in business activities as partners that are latent-discretionary or have the legitimacy in providing the business fund.

\section{Non-Governmental Organization (NGO)}

Social entrepreneur activities that involve and require the resources from the environment will attract the attention of non-governmental organizations engaged in related fields. According to experts, the empowerment of NGOs and the environment will be latent-dormant in the activities of the vaname sea shrimp cultivation business.

Financial Institution, SME, Travel Agent Industry

Financial Institution, SME, and travel agent industry are the stakeholders which are latent-demanding. All three only have the force of urgency, which means that they will only be involved in activities if they receive a response from the business actors. The response given will be able to help the company to develop the business.

\section{Public Figure}

This stakeholder is the people or figure who has an important role or influence in the local community. The public figures are very important to mobilize the cultivation and to move and change the people's behavior so that it has an expected-dangerous nature.

\section{Supplier}

The feed and benur suppliers are expected-dominant because they have the power and urgency of the company's operations. Both suppliers have a role in maintaining the business continuity and can urge the companies to make the agreements in purchasing the transaction activities to ensure the availability of the quality of being and feed.

\section{End Consumer}

The consumer is the expected-dependent stakeholder, namely having legitimacy and urgency. In this case, the shrimp consumer has a legitimate right to involve themselves in consuming the shrimp and to influence the management according to their desired needs (bargaining power).

\section{Analysis of Stakeholder Dependence}

A company needs an appropriate and directed strategy in dealing with each stakeholder. An analysis of the relationship of dependence in each stakeholder of a business can help the organization devote the resources (material, time, and energy) proportionally according to their strengths and interests. This process can also be used to find out and anticipate the conflicts of importance for the organizations and the stakeholders, and to find ways to prevent them. According to Barton (2011), understanding like this must be done to create long-term value (the value maximization).

Each stakeholder has different characteristics and dependence relationships towards the company so that it requires a different approach. Frooman (1999) provides a guide for analyzing the company's dependence on the stakeholders through a matrix. The matrix describes which stakeholders depend on the company and vice versa. The relation between company and stakeholder can be distinguished into four characteristics, namely low interdependence, firm power, stakeholder power, 
and high interdependence. The results of the analysis of stakeholder dependence on the social entrepreneur in the vaname shrimp cultivation business can be seen in Figure 3.

The results of the dependency mapping show that the vaname shrimp cultivation business based on the social entrepreneur has dependency on the internal stakeholders, namely the head of the business groups, the financial, operational, and marketing technicians, and the suppliers and Private CSR. The stakeholder includes having high interdependence because they depend on each other. While other key stakeholders that must be involved in the business activities are the stakeholder groups that are included in the stakeholder power quadrant, which include consumers, public figures, higher education, and research institute, and the travel agent industry. In this group, the company has a high dependency on improving and develop the business scale.

\section{Managerial Implications}

\section{Establishment of New Business Group}

The social entrepreneur business actors are the KAKS community groups. The members of this group must be formed based on the common vision, which is to increase the income /economy of the members and the welfare of the community in general. According to Hubeis and Najib (2008), the existence of the group organized as an organization allows the achievement of the organizational goals to be easier because of the collaboration between the individuals that allow the synergy between potentials. The synergy is the accumulation of the group strength, which exceeds the sum of each individual if he works. The existence of the business group that manages the vaname shrimp cultivation is expected to attract the tourists and open the employment opportunities for the surrounding community. The formation of the groups is also intended to shape the organizational structure and the roles (duties and obligations) of each member so that the business management is carried out professionally.

\section{Institutional Initiation of Social Entrepreneur}

The implementation of the social entrepreneur program, in general, requires the role of many parties. The institutional formation is needed to accommodate the role and involvement of stakeholders such as the research institutions, CSR of the private companies, and the local governments. The existence of the institution is expected to maximize the tasks and roles of each to succeed in the social entrepreneur program. One of the main roles needed is mentoring. Based on the results of the analysis of the internal aspects that have been done, mentoring is an aspect that is considered very important to be considered. The mentoring to the business group is aimed at strengthening groups from the business realization, the technical and operational implementation, the financial management, the organizational and group management, the market management, and the consumers.

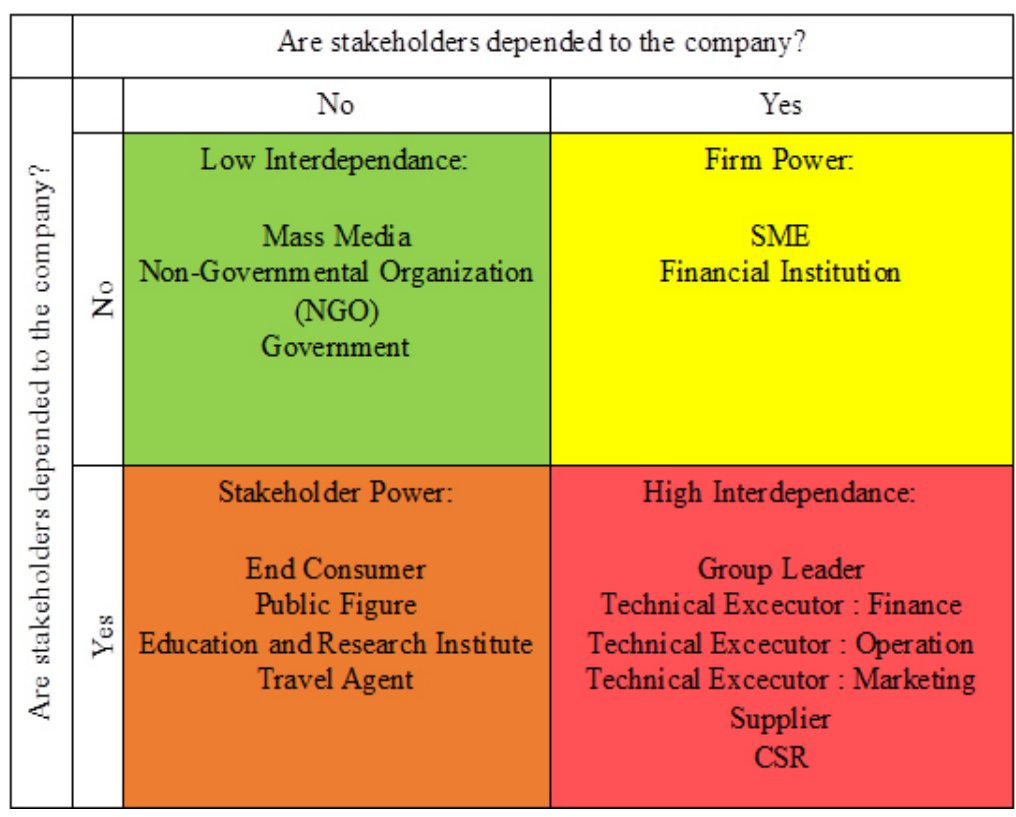

Figure 3. Analysis of stakeholder dependence 


\section{CONCLUSIONS AND RECOMMENDATIONS}

\section{Conclusions}

The classification of the stakeholders based on the typology shows that the role of the group leader is definite, which has the highest characteristics so that his voice will dominate and have a significant effect on the performance of the business activities. Analysis of stakeholder dependence is influenced by the High Interdependence consisting of the group leader, the operational, financial and marketing executives, the suppliers and private companies, and the Power Stakeholder consisting of the end consumers, the communityfigures, thelocalgovernment, theeducational and research institutions. Stakeholder analysis can be used as the reference and the input for the development of a social business model for the social entrepreneur of the vaname sea shrimp cultivation that involves many parties, especially the community.

\section{Recommendations}

The existence of the stakeholders influences the sustainability of business activities. Further research can be continued to analyze business continuity. The study of the social entrepreneurship model of the vaname sea shrimp farming business can be done to strengthen the role of the established business group.

\section{REFERENCES}

Hidayatillah Y. 2017. Dampak sosial industrialisasi tambak udang terhadap lingkungan desa andalang di Desa Andalang Kabupaten Sumenep. Theory and Practical Journal of IPS Learning 2(2): 21-26.

Surya WD, Saefuddin A, Soemardjo. 2002. Pemberdayaan Masyarakat Pesisir untuk Meningkatkan Kesejahteraan Keluarga Nelayan: Studi Kasus Tanjung Pakis, Kabupaten Karawang, Jawa Barat. Bogor: Pustaka Crescent.

Susanto H. 2015. Optimalisasi Manajemen Risiko melalui Peningkatan Pemahaman Nilai Stakeholder Berbasis ISO 31000. Bogor: Bogor Agricultural University.

Osterwalder A, Pigneur Y. 2015. Business Model Generation (Translation). Jakarta: PT Alex Media Komputindo.

Susilo LJ, Kaho VR. 2011. Panduan Manajemen Risiko Berbasis ISO 31000 Industri Non Perbankan. Jakarta: PPM Manajemen.

Frooman J. 1999. Stakeholder influence startegies. Academy of Management Review 24(2): 191205

Hubeis M, Najib M. 2008. Manajemen Strategi dalam Pengembangan Daya Saing Organisasi. Jakarta: Gramedia. 